\title{
Hemibalism apărut la un pacient diagnosticat cu sindromul imunodeficienței umane dobândite şi toxoplasmoză
}

\author{
Simona Claudia Cambrea ${ }^{1,2}$, Corina Pascu ${ }^{3}$, Sorin Rugină ${ }^{1,2}$ \\ ${ }^{1}$ Spitalul Clinic de Boli Infecţioase, Constanţa, România \\ ${ }^{2}$ Clinica de Boli Infecţioase, Facultatea de Medicina Generală, \\ Universitatea „Ovidius", Constanţa, România \\ ${ }^{3}$ Clinica de Neurologie, Facultatea de Medicina Generală, \\ Universitatea „Ovidius", Constanţa, România
}

\begin{abstract}
REZUMAT
Apariția tulburărilor de mişcare de tip hemicoree-hemibalism la pacienții diagnosticați cu toxoplasmoză cerebrală, este una neobişnuită. Unele studii raportează frecvența acestor tulburări de mişcare pe locul doi, după parkinsonism (1). Vom prezenta cazul unei paciente în vârstă de 28 de ani, cu toxoplasmoză recidivantă, manifestată clinic sub forma hemibalismului la nivelul membrelor drepte. În ciuda tratamentului instituit, s-a obținut doar o ameliorare a tulburării de mişcare.
\end{abstract}

Cuvinte cheie: hemibalism, toxoplasmoză

\section{INTRODUCERE}

Deși incidența în Europa a toxoplasmozei cerebrale s-a redus drastic în urma instituirii terapiei antiretrovirale combinate(cART) (2), aceasta rămâne cea mai importantă infecție oportunistă neurologică în cazul pacienților infectați HIV. Toxoplasma gondii are afinitate pentru sistemul nervos central și recăderi pot apărea chiar și după lungi perioade de timp, din cauza persistenței intracerebrale. Afectarea nucleului subtalamic sau a conexiunilor sale palidale duce la apariția hemibalismului și coreoatetozei.

\section{PREZENTAREA CAZULUI}

Prezentăm cazul unei paciente în vârstă de 28 de ani care face parte din cohorta româneas- că de copii infectați cu F1 HIV. A fost diagnosticată cu HIV în 1995, la vârsta de 7 ani și de atunci a prezentat multiple infecții respiratorii, candidoză muco-cutanată cronică, hepatomegalie, varicela diseminată, hipotrofie staturo-ponderală și hepatita cu virus B.

S-a inițiat terapia cART în 2004 cu o combinație de inhibitori de revers transcriptază (lamivudină și zidovudină), inhibitori de protează (lopinavir/ritonavir) și inhibitori non-nucleozidici de revers transcriptază (efavirenz). Începând cu 2006 și până în 2016 a urmat schema abacavir + zidovudină + lamivudină și lopinavir/ritonavir.

Pacienta are o aderență scăzută la tratament. Graficele descriu fluctuațiile nivelului CD4 și a încărcăturii virale din 2001 până în 2016 (Fig. 1, 2). În 2015, pacienta s-a prezentat în urgență cu 


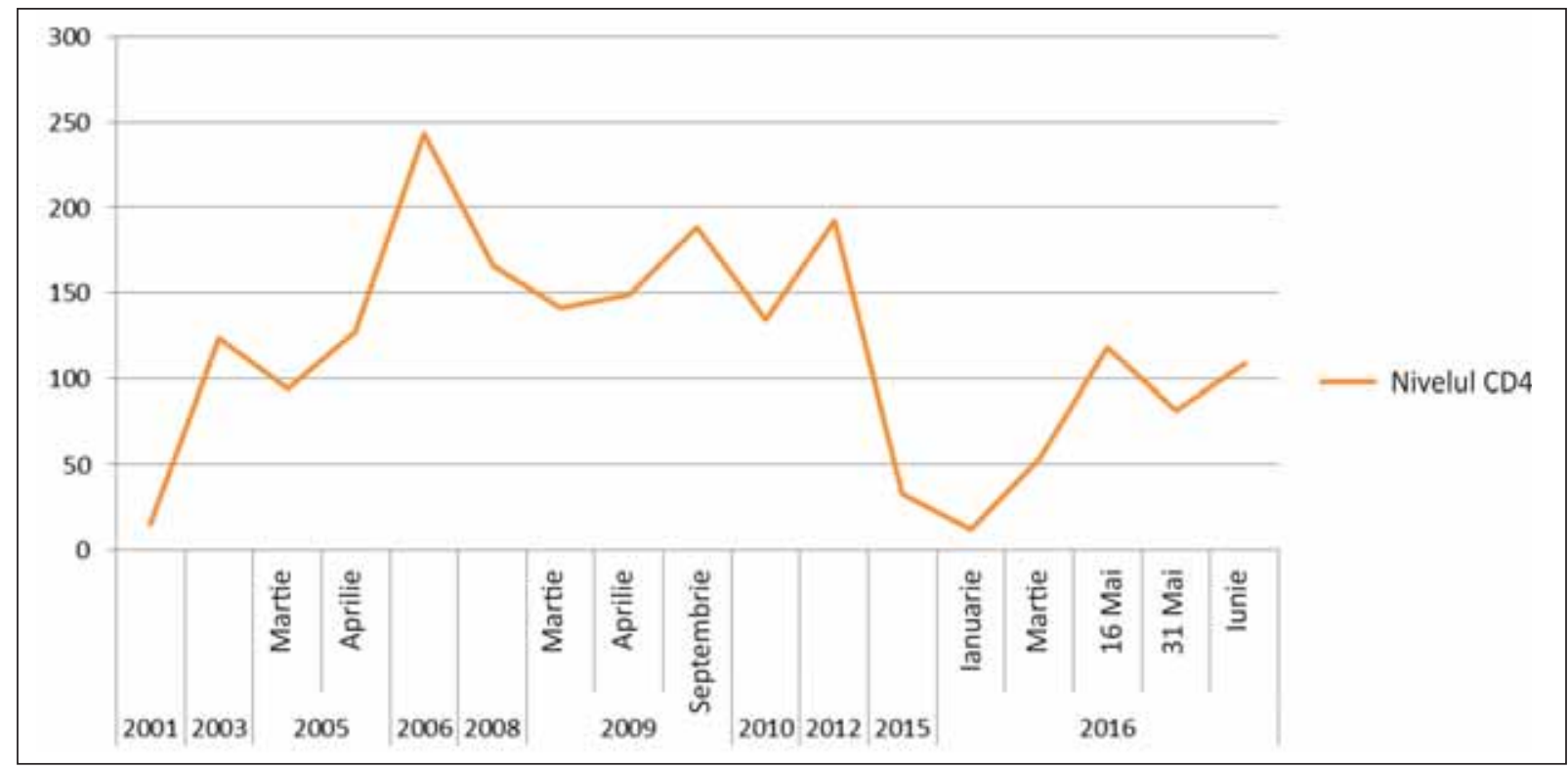

FIGURA 1. Evoluția nivelului CD4

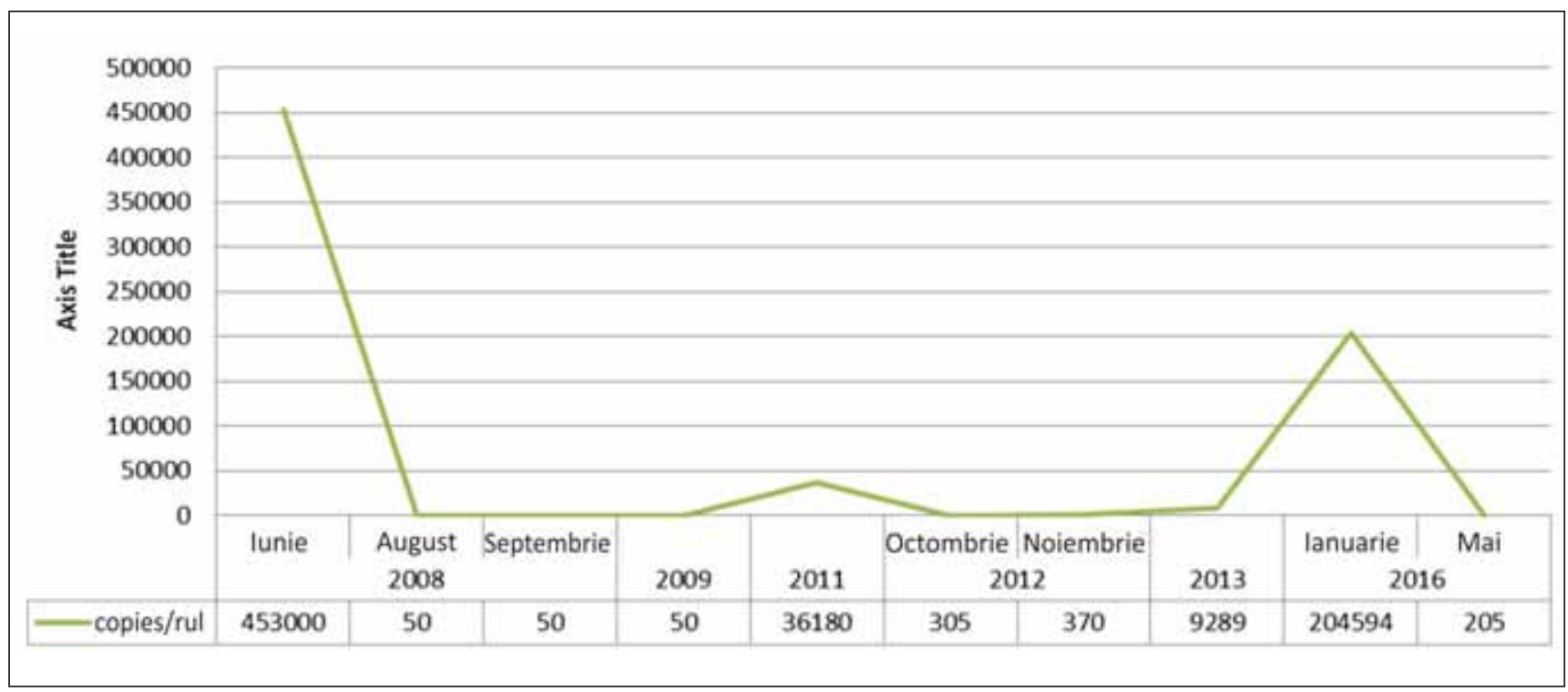

FIGURE 2. Evoluția încărcăturii virale

deficit motor al membrelor stângi, cu debut brusc după o criză de pierdere de conștiență. RMN-ul cerebral a indicat mase nodulare bine delimitate. Aceste leziuni erau hiperintense T2 cu prindere de contrast inelară și înconjurate de edem. Localizarea lor era la nivel subcortical frontal dreapta, subcortical frontal stânga și la nivelul capului nucleului caudat (Fig. 3, 4a, 4b, 4c).

Nivelul CD 4 a fost 33 celule/mmc, iar anticorpii IgM Toxoplasma în ser au fost negativi. Pacienta a primit tratament cu cotrimoxazol $2 \mathrm{cp} \mathrm{a}$ câte 960 mg de 3 ori pe zi timp de 6 săptămâni. Răspunsul la tratament a fost unul pozitiv, ame-

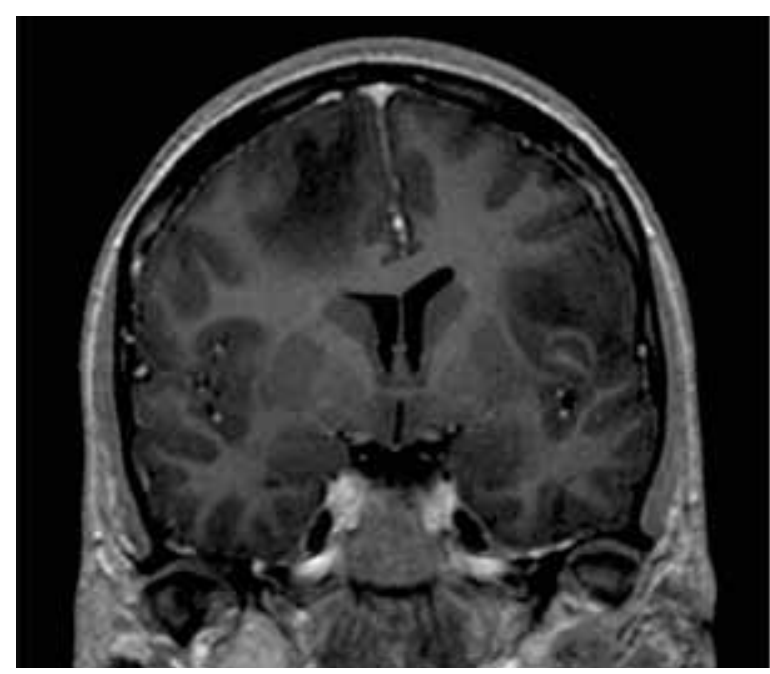

FIGURA 3. RMN cerebral: leziune hipointensă T1 în secțiune coronală, cu priză de contrast inelară, localizată frontal stânga 


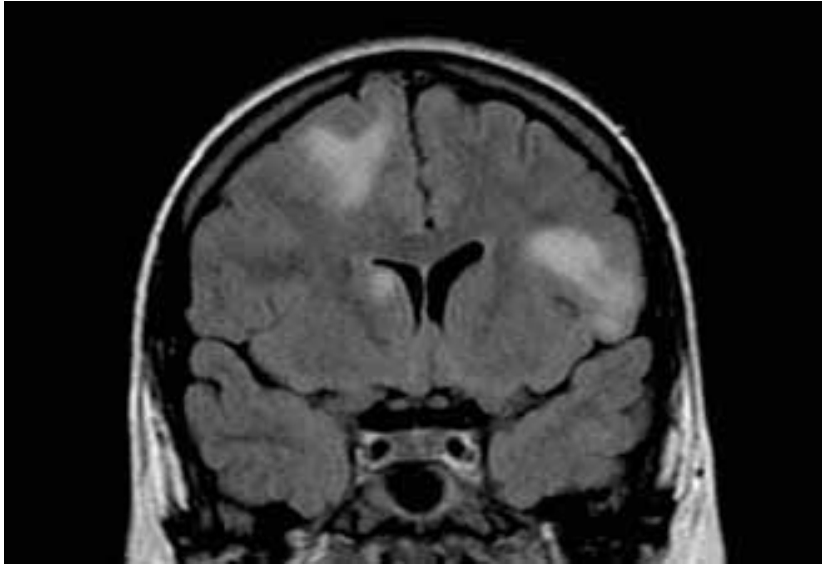

FIGURA 4A. RMN cerebral, leziuni hiperintense T2, vizibile pe secțiunile coronale la nivel frontal subcortical bilateral şi la nivelul capului nucleului caudat drept

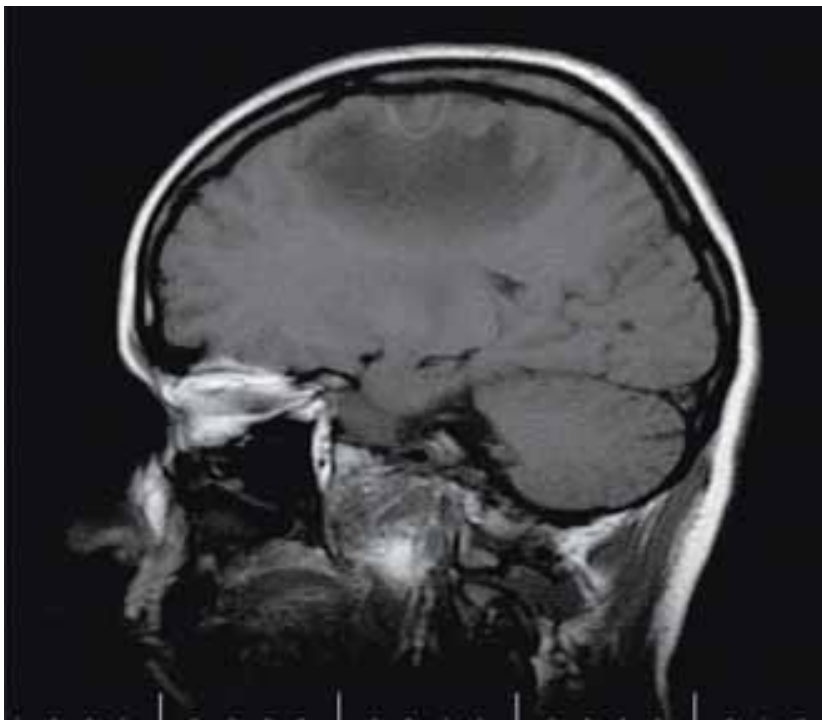

FIGURA 4B. IRM scan, pe secțiunile sagitale în secvență T1 se vizualizează masă nodulară localizată frontal şi înconjurată de edem

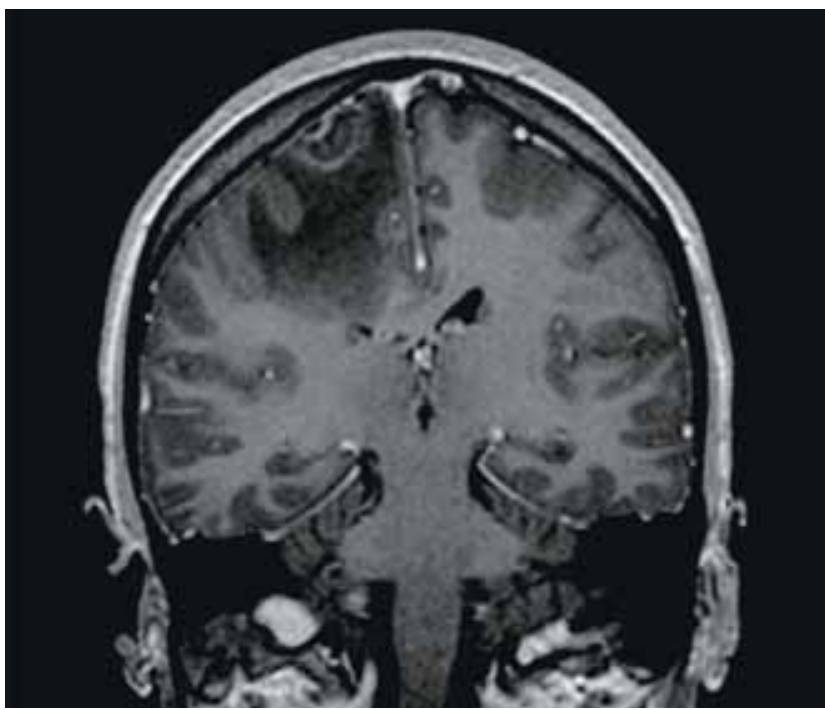

FIGURA 4C. IRM scan, secvență T1, secțiune coronală, după administrare de contrast: masă nodulară cu priză de contrast inelară localizată frontal liorarea simptomatologiei fiind remarcată în primele 14 zile. În ciuda profilaxiei secundare cu cotrimoxazol, pacienta se prezintă cu recădere

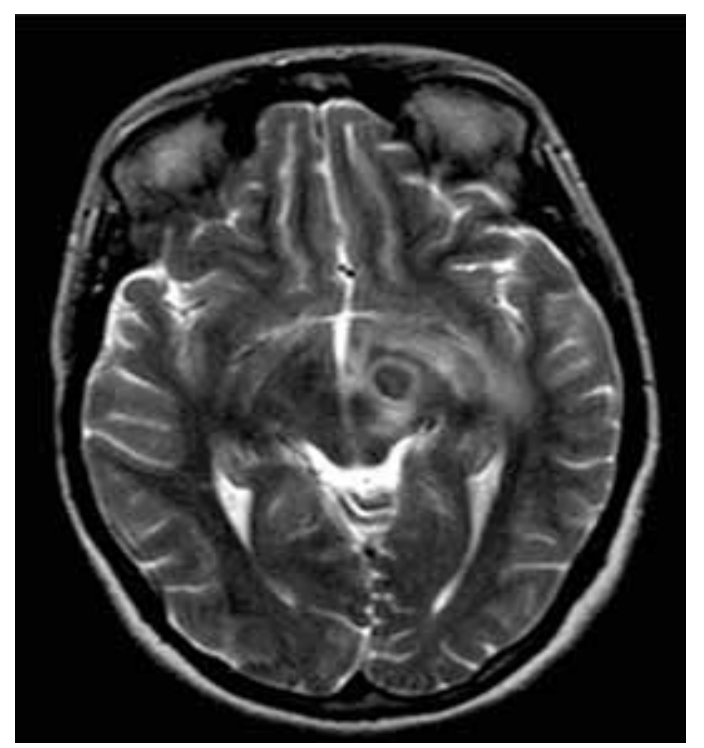

FIGURA 5A. RMN cerebral: leziune nodulară localizată temporal profund, cu diametrul de $13 \mathrm{~mm}$, iso-hipointensă T2 cu margini hiperintense

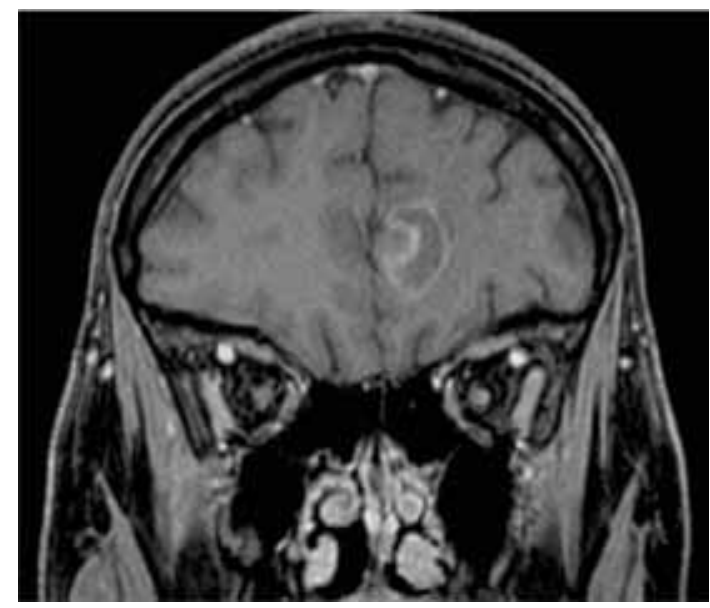

FIGURA 5B. RMN cerebral: leziune nodulară localizată parasagital frontal stânga, cu diametrul de 12/9 mm, hipointensă T1 cu margini hiperintense

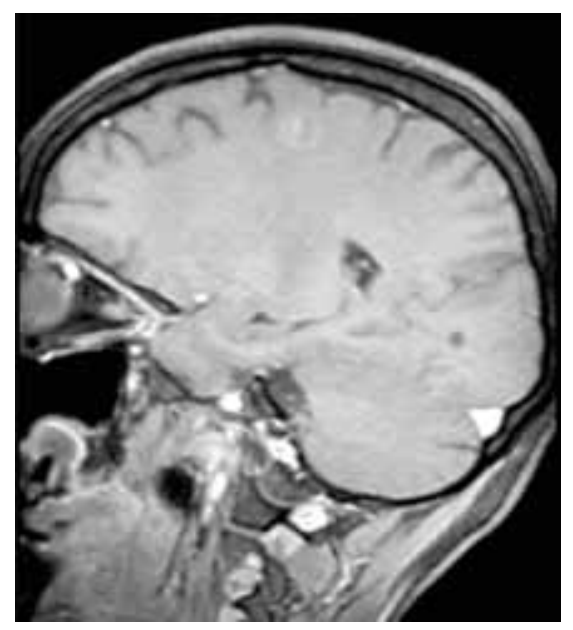

FIGURA 5C.

RMN cerebral: leziune nodulară localizată frontal, cu un diametru de 11 mm, cu priză de contrast inelară şi prindere de contrast heterogenă la nivel central 
în martie 2016, manifestată clinic drept hemibalism al membrelor drepte. A mărturisit ulterior

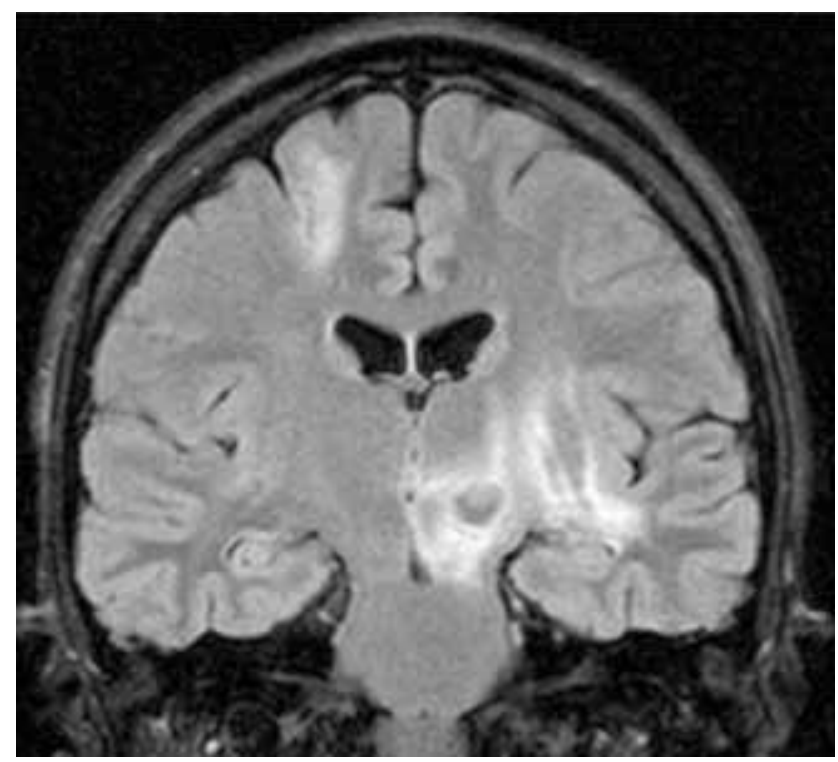

FIGURA 6A. RMN cerebral: secvențele T2 coronale evidențiază leziunea mezencefalică stângă înconjurată de edem, precum şi leziunile de la nivelul emisferului cerebral stâng şi frontal dreapta

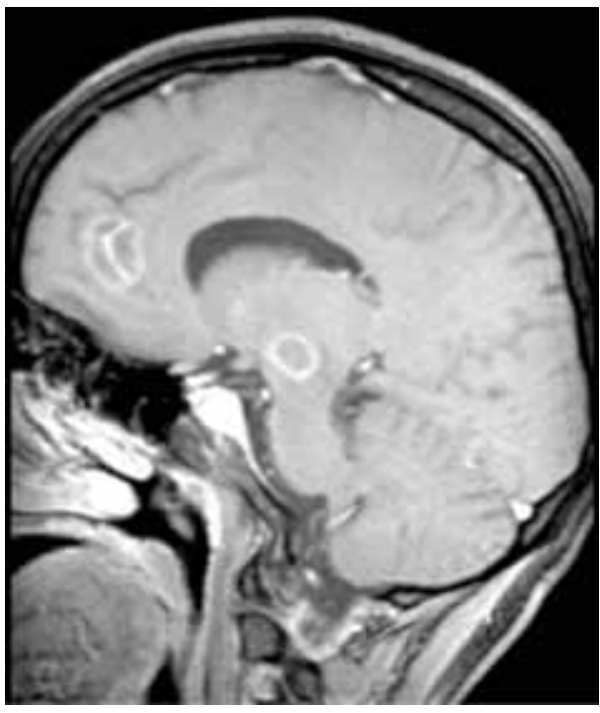

FIGURA 6B.

RMN cere-

bral: leziuni

confluate la

nivel frontal

prezum şio

leziune

mezencefali-

că evidentiate

pe secțiunile

sagitale; toate

leziunile

prezintă priză

de contrast

inelară

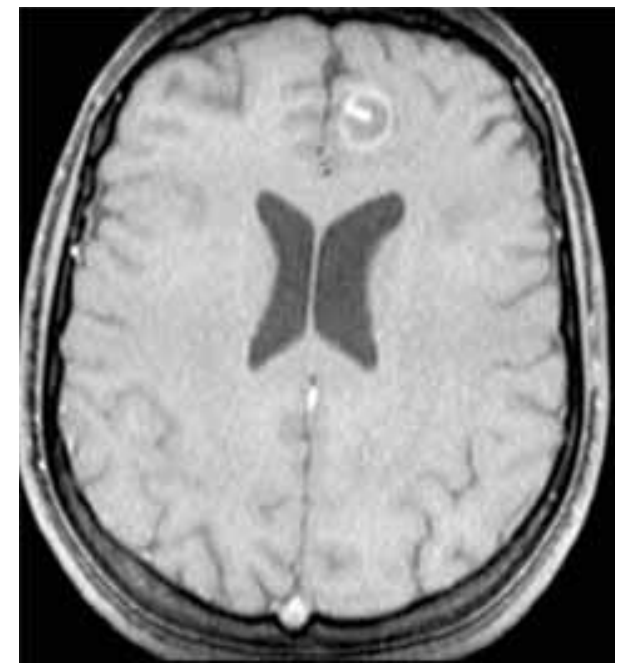

FIGURA 6C.

RMN cerebral: leziune

localizată la

nivelul

girusului

cingulat stâng

cu priză de

contrast

centrală

heterogenă faptul că stopase atât cART, cât și profilaxia secundară cu cotrimoxazol.

RMN cerebral efectuat a arătat noi leziuni, inclusiv cea de la nivelulul nucleului subtalamic (Fig. 5).

S-a inițiat tratamentul etiologic pentru toxoplasmoză cerebrală cu cotrimoxazol și clindamicină pentru 6 săptămâni și s-a recomandat profilaxia secundară cu cotrimoxazol. Haloperidolul, trihexifenidilul și acidul valproic nu au putut ameliora tulburarea de mișcare. Ameliorarea

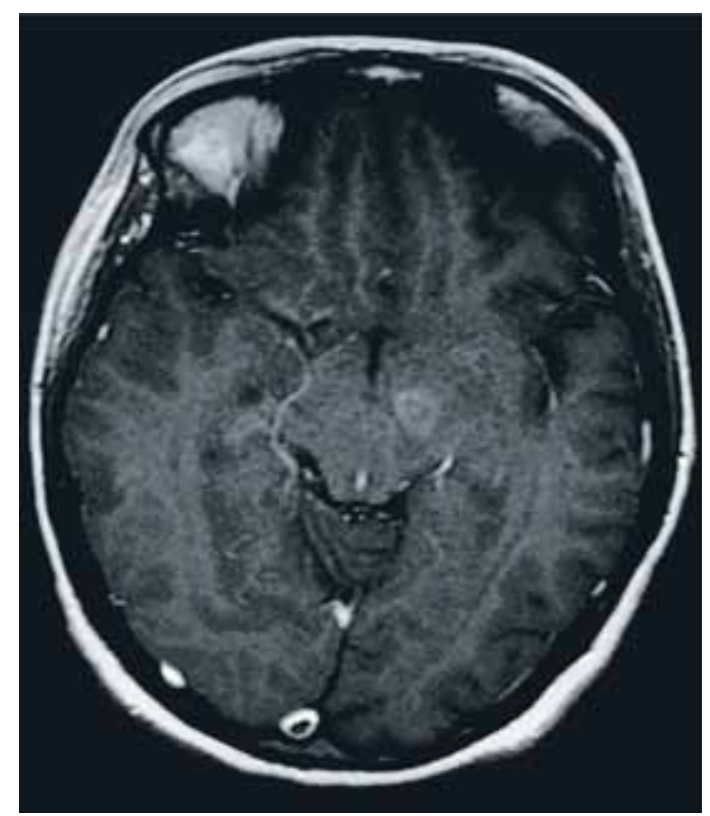

FIGURA 6D. RMN cerebral: leziuni izointense T1 cu priză de contrast inelară, localizate la nivelul mezencefalului

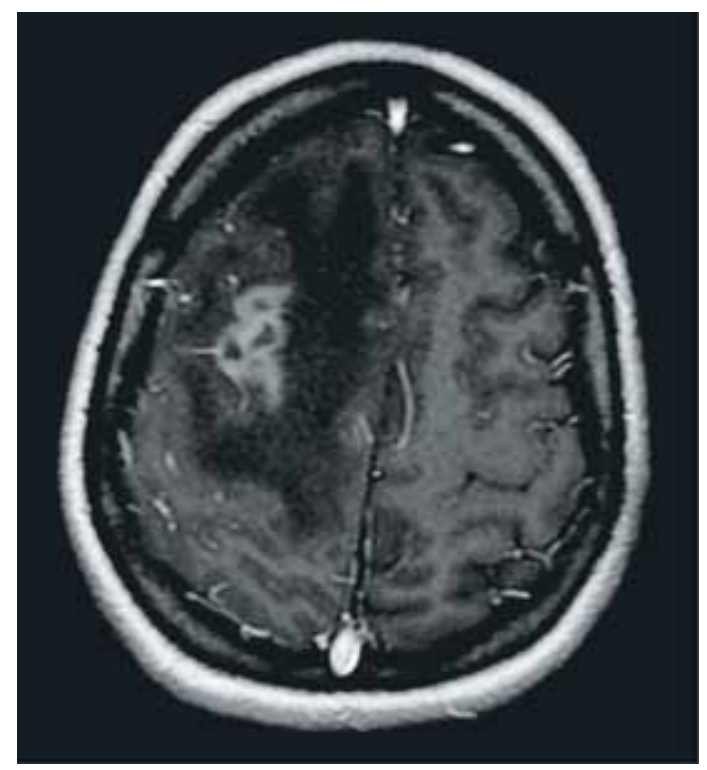

FIGURA 6E. RMN cerebral: leziuni izo-hipointense T1 localizate frontal dreapta, înconjurate de vast edem vizibil ca zonă hipointensă 


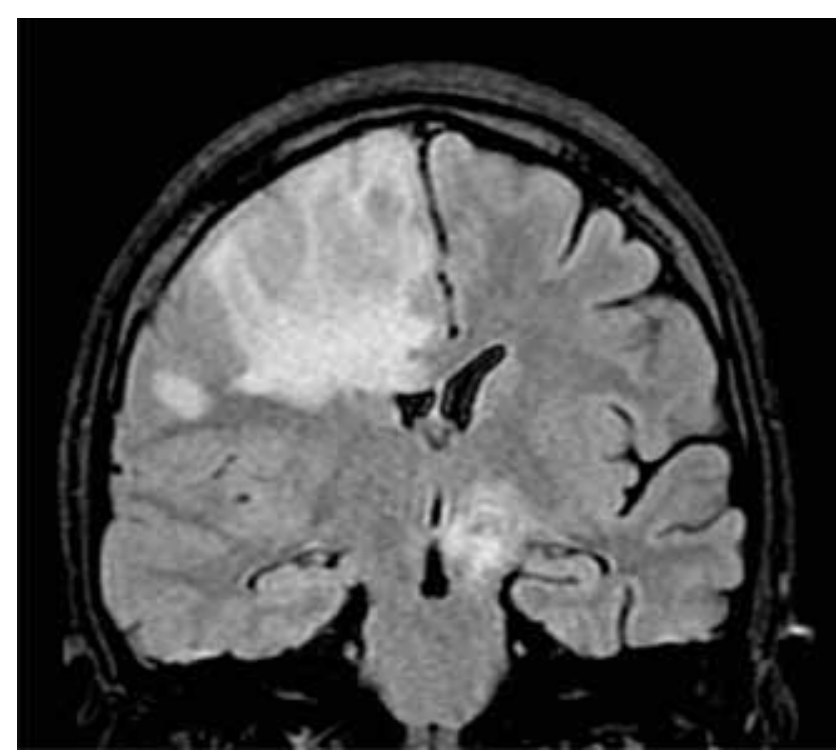

FIGURA 6F. RMN cerebral: secțiunile T2, coronale, evidențiază vastul edem şi efectul de masă cauzate de leziunile de la nivel frontal dreapta

simptomatologiei s-a observat abia după ce s-a înlocuit acidul valproic cu clonazepam. După o lună s-a efectuat un nou RMN cerebral (Fig. 6). S-au evidențiat cu această ocazie noi leziuni cerebrale la nivel frontal dreapta, la nivelul emisferei cerebrale stângi și la nivel mezencefalic. Leziunile de la nivelul emisferului cerebral drept au tendința la confluare, sunt înconjurate de edem și determină efect de masă. Leziunile de la nivelul emisferului cerebral stâng și cea de la nivel mezencefalic sunt înconjurate de edem minimal.

La controlul după 5 luni, pacienta a prezentat ameliorarea mișcărilor involuntare. A continuat profilaxia secundară pentru toxoplasmoză cerebrală precum și cART.

\section{DISCUȚII}

Apariția mișcărilor involuntare la pacienții infectați HIV-SIDA este semnalată din ce în ce mai frecvent în ultima perioadă. Factorii etiologici includ encefalopatia HIV, leucoencefalopatia multifocală progresivă, boala Whipple și consumul de medicamente ce pot induce tulburări de mișcare $(4,5)$. În orice caz, una dintre cele mai frecvente cauze semnalate în apariția tulburărilor de mișcare la pacienții cu SIDA, este toxoplasmoza cerebrală (6). Toxoplasmoza este una dintre cele mai frecvente infecții oportuniste cerebrale la bolnavii cu SIDA, responsabilă în studiile postmortem $<=30 \%$, mai ales când nivelul CD4<300/mm c (7).

Majoritatea pacienților cu SIDA la care s-a semnalat apariția coreei, balismului, au prezentat leziuni multiple cerebrale, mai puțin leziuni solitare. Leziunile tumoră-like provoacă frecvent hipertensiune intracraniană, stare confuzională și/sau semne focale de tip piramidal. Tulburările de mișcare sunt rar semnalate când sunt prezente astfel de leziuni; dar atunci când apar, cel mai frecvent sunt sub forma hemicoree-balism sau hemicoree-atetoză (8). Structurile cerebrale cel mai frecvent afectate sunt nucleul subtalamic, talamusul, capul nucleului caudat, putamenul, globus palidus, mezencefalul și capsula internă $(6,9)$. În cazul prezentat, diagnosticul de toxoplasmoză s-a bazat pe neuroimagistică și răspunsul la terapia specifică, neefectuându-se biopsie cerebrală. Neuroimagistica a evidențiat leziuni ce pot explica apariţia hemibalismului în ambele emisfere cerebrale. În emisferul cerebral drept, leziunea glială situată la nivelul capului nucleului caudat. În emisferul cerebral stâng, leziunea de dimensiuni mai mari și activă, descrisă în regiunea nucleului subtalamic stâng. Întrucât debutul tulburării de mișcare s-a corelat cu apariția acestei a doua leziuni, presupunem că este cea care a declanșat simptomatologia.

Chiar dacă pacienta a răspuns, în primă instanță, la tratament, recăderea cu apariția noilor simptome se explică probabil printr-o aderență scăzută la terapia cART, dar și la tratamentul de menţinere anti-toxoplasmă. Hemibalismul a răspuns la tratament, dar persistă într-o oarecare măsură, ca și leziunea care l-a provocat.

\section{CONCLUZII}

Mișcările involuntare precum hemibalismul, chiar dacă sunt rare, pot să apară la pacienții infectați HIV-SIDA care prezintă, cel mai frecvent, leziuni multiple de toxoplasmoză cerebrală. 
În faza acută, este destul de dificil de obținut controlul terapeutic al acestor tulburări de mișcare utilizând tratament neurologic.

Evoluția favorabilă a simptomatologiei a fost remarcată, probabil, când leziunea cerebrală a scăzut în dimensiuni sub tratament etiologic pentru toxoplasmoză cerebrală și cART.

Conflict of interest: none declared Financial support: none declared 